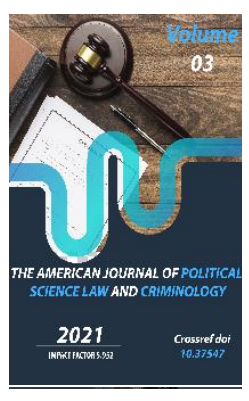

\title{
Prosecutors' Offices In The Protection Of Labour Rights: Is There A Need For Improving The Legislation Of Uzbekistan
}

Habibulla Mirsoatov

Independent Researcher At Tashkent State University Of Law, Uzbekistan

Journal Website: http://usajournalshub.c om/index,php/tajpslc

Copyright: Original content from this work may be used under the terms of the creative commons attributes 4.0 licence.

\section{ABSTRACT}

The author of the article analyzes organizational and legal framework for the implementation of legal reforms in labour law in Uzbekistan. It is important to improve the role of the prosecutors' offices in ensuring the constitutional rights of citizens to work in Uzbekistan, to bring the legislation in line with international standards through inventory. Based on the analysis of national and international experience, the author analyzes the reforms implemented in Uzbekistan in this sphere. The author's conclusions are put forward at the end of the article.

\section{KEYWORDS}

Labour law, prosecutors' offices, fair working conditions, International Labour Organization, age of employment.

\section{INTRODUCTION}

I. National labour legislation in imposition of special responsibilities on states Uzbekistan in these processes are becoming increasingly global and relevant in the world. These The issues of human rights, the right to fair labour, which is an integral part of it, and the processes are particularly evident in the issues of ensuring gender equality, protecting the 
rights of young people to work, and preventing child labour. In particular, UN Resolution 71/237 of 21 December 2016 on International Migration and Development states that the efforts of states in labour are insufficient, and this sphere is one of the most pressing issues in the life of individuals, society and the state at the national, regional and international levels. In this regard, the international community emphasizes the need for further enhancing international cooperation in labour in all countries, carrying out legal reforms aimed at protecting the rights and legitimate interests of workers.

The main attention is paid to strengthening the national legislation for improving the sphere by constitutional legal protection of labour relations in the world, increasing the responsibility of law enforcement agencies in this field, identification of specific areas of legal regulation of the participation of nongovernmental non-profit organizations and other civil society institutions. In particular, guaranteeing the rights of minors in labour, improving the institutional framework of institutions that ensure the rights of women and people with disabilities at the national level, introducing smart regulation models and developing more effective mechanisms for the legal settlement of labour disputes and strengthening the implementation of international standards are important in the legal regulation of related issues.

In Uzbekistan, special attention is paid to the role of the prosecutor's office in ensuring the constitutional rights for ensuring labour rights, comprehensive legal protection of the interests of employees and its adaptation to international standards. Several targeted measures have been taken and the sector has developed to a certain extent. In particular, large-scale systematic work is being carried out to increase the role and importance of labour relations and employment in public policy, to improve public administration through administrative reforms in this area, to ratify international conventions in labour, to protect workers' rights.

"Creating new jobs and ensuring the employment of the population, especially graduates of secondary special and higher education institutions, ensuring the balance of the labour market and infrastructure development, reducing unemployment. Creating conditions for the full implementation of labour and entrepreneurial activity of the able-bodied population, improving the quality of labour, expanding the system of vocational training, retraining and advanced training of people in need" are identified as one of the priorities in the development of the social sphere, the study of this area is becoming important.

Article 37 of the Constitution of the Republic of Uzbekistan states: "Everyone shall have the right to work, including the right to choose their occupation. Every citizen shall be entitled to fair conditions of labour and protection against unemployment in accordance with the procedure prescribed by law".

This constitutional legal norm fully complies with the universally recognized norm enshrined in Article 23 of the Universal Declaration of Human Rights, stating that "Everyone has the right to work, to free choice of employment, to just and favourable conditions of work and to protection against unemployment". In the national legislation, this norm is reflected in several legislative acts, such as Law “On Trade Unions" (2019), “On 
Employment” (2020), “On Private Employment Agencies" (2018), Decree of the President of the Republic of Uzbekistan No. DP-5052 of May 24, 2017 "On measures to further improve the state policy in employment and radically increase the efficiency of labour bodies", Resolution of the President of the Republic of Uzbekistan "On measures to organize the activities of the Ministry of Employment and Labour Relations of the Republic of Uzbekistan" of May 24, 2017, No. RP-3001.

In particular, A.A. Inoyatov, M.A. Usmanova, M.Yu. Gasanov, Yu. Tursunov, G.D. Sattarova, Sh.A. Ismoilov, Z.S. Rasulov, M.A. Rakhimov, B. Musayev covered labour law and its implementation in their scientific research. Opinions on the constitutional legal aspects of these issues and strengthening of constitutionalism in ensuring human rights have been analyzed in the scientific works of Sh. Yakubov, I. Bekov, B. Narimanov, B. Kasimov, K. Aliyeva, H. Batirov, L. Arslonova and others.

The role of the prosecutor's office in the law enforcement system is important in ensuring the labour legislation. According to Article 118 of the Constitution of the Republic of Uzbekistan, The Procurator-General of the Republic of Uzbekistan and the procurators subordinate to him shall supervise the strict and uniform observance of laws on the territory of the Republic of Uzbekistan.

Also, according to Article 9 of the Labour Code, supervision of exact and uniform execution of the laws on work in the territory of the Republic of Uzbekistan is performed by the Attorney-General of the Republic of Uzbekistan and prosecutors subordinated to it. According to Article 25 of the Law "On the Prosecutor's Office" (new edition), the prosecutor considers and investigates applications, complaints about violations of the rights and freedoms of citizens in the process of monitoring their observance.

Within the framework of the protection of employees' labour rights, prosecutors conduct prosecutorial investigations, review appeals, and file claims in the courts.

According to the statistics, the prosecutor's office identified 2,079 violations of labour legislation in 2018 and 11,265 in 2019. In 2019, the prosecutor's office considered 29,889 appeals on labour laws, of which 10,629 were satisfied, and the violated rights of 10,896 people were restored. In 2018, 4.8 billion UZS of overdue salaries of 3,589 citizens were compensated. The analysis of the figures shows that the prosecutor's office plays an important role in the protection of labour rights.

\section{Existing practice and its improvement}

There are cases of non-compliance with labour legislation by private enterprises, individual entrepreneurs, employers and individuals.

They are manifested in the following:

first, recruitment violations: unreasonable refusal to hire while there are jobs, discrimination based on age and gender, concealment of jobs, including unjustified staffing of budgetary organizations with nonspecialist staff, non-compliance with the requirements for the conclusion of fixed-term employment contracts, informal use of citizens without an employment contract;

second, labour and rest period violations: nonpayment of wages on time, unlawful 
withholding from employment, discrimination during incentives, guarantee and compensation payments, overpayments, violations related to overtime, non-compliance with the procedure for granting leave, use without leave for several years;

thirdly, violations in the process of termination of the employment contract: illegal termination of the employment contract, when the enterprise is reorganized, the negative practice of dismissing employees when their name is changed and then re-hiring them to the employer's approval, coercion to dismiss, various pressures, failure to pay on time when the contract is terminated, nonissuance of the employment record book, advance notice in the process of termination of the contract, failure to obtain the consent of the representative bodies, non-payment of dismissal benefits, etc.

\section{Foreign experience in labour protection}

Prosecutors in the CIS countries monitor the implementation of labour laws. For example, according to the Labour Code of the Russian Federation (Labour Code RF No. 197-FZ), a prosecutor has the authority to apply to the court to protect the interests of the employee, to conduct unscheduled inspections of compliance with labour legislation, to review appeals. In other foreign countries, the prosecutor's office is not the main competent authority in labour protection. For example, the United States Attorney, according to the legislation (28 U.S. Code § 547) prosecutes crimes against the state under the law, protects the interests of the Government in criminal and civil cases. In England and Wales, the Crown Prosecution Service under the Act (Prosecution of Offenses Act 1985) investigates criminal cases initiated by the police and other investigative bodies, identifies charges in serious or complex cases, prepares and submits criminal cases, and assists victims and witnesses.

\section{Suggestions and opinions}

The following is proposed to increase the effectiveness of the prosecutor's office in labour protection:

1. It is necessary to conduct a systematic analysis of the current situation based on the information provided by law enforcement, regulatory agencies, public associations, trade unions, as well as the interdepartmental software and hardware complex "Single National Labour System". Under the requirements of the Law "On transparency of activities of the state governing bodies and administration", quarterly reports on identified violations and measures taken against them should be regularly published on the official website of the prosecutor's office.

2. According to the International Labour Organization (Third-party monitoring of child labour and forced labour during the 2020 cotton harvest in Uzbekistan // International Labour Organization, Fundamental Principles and Rights at Work Branch, Geneva: ILO, 2021.), 42 officials, including heads of organizations, hokims and their deputies, were prosecuted under Article 51 of the Administrative Responsibility Code for forced labour during the 2020 cotton 
harvest, and relevant documents were submitted to the courts in 6 cases.

3. It is proposed to cooperate with Uzbekistan Trade Unions Federation on unreasonable denial of employment, concealment of jobs, violation of the requirements for the conclusion of fixedterm employment contracts and other violations.

4. It is proposed to supplement the Administrative Responsibility Code with Article 2551, called the Prosecutor's Office to prevent forced labour and human trafficking cases.

In this case, the staff of the Prosecutor's Office is authorized to conduct proceedings on administrative offenses under Article 501 (violation of the legislation on private employment agencies), 51 (Administrative enforcement of labour). This function is removed from the competence of the State Labour Inspectorate. As a result of the implementation of the proposal, the requirements of Conventions No. 29 of 1930 on "Forced and compulsory labour" and No. 105 of on the "Abolition of forced labour" will be implemented.

5. To ensure the prosecutor's control over the activities of the commission of inquiry in the event of a group death and serious accidents at the enterprise, it is proposed to add paragraph 11 "It is necessary to establish prosecutorial control over the special investigation of accidents in the prescribed manner" to the chapter 3 "Special investigation of accidents" of the Regulation "On the investigation and accounting of industrial accidents and other damage to the health of employees in connection with the performance of work duties", approved by the Resolution of the Cabinet of Ministers No. 286 of June 6, 1997.

6. Introduction of the procedure for ensuring the participation of the prosecutor in the process of consideration of disputes on payment by the employer in the courts of civil cases when performing labour duties provided for in Article 269 of the Labour Code, the damage to the employee's health (including moral damage) or damage to his/her property, and this should be fixed by the order of the Attorney General.

Based on the above, it can be concluded that increasing the role of government agencies, especially the prosecutor's office, in ensuring the rights and freedoms of citizens in the process of reforms in our country is one of the urgent tasks.

\section{REFERENCES}

1. www.un.org, www.ilo.org

2. Б.Мусаев ПРАВОВЫЕ МЕХАНИЗМЫ ПРИВЛЕЧЕНИЯ НА РАБОТУ ИНОСТРАННЫХ ГРАЖДАН В УЗБЕКИСТАНЕ // Review of law sciences. $2018 . \quad$ №3. URL: https://cyberleninka.ru/article/n/pravovyemehanizmy-privlecheniya-na-rabotuinostrannyh-grazhdan-v-uzbekistane (дата обращения: 03.04.2021).

3. МУСАЕВ, Б., 2021. МЕХНАТ МИГРАЦИЯСИ ВА БАНДЛИК СОХАСИДА ХУСУСИЙ БАНДЛИК АГЕНТЛИКЛАРИ ФАОЛИЯТИНИНГ ХУҚУҚИЙ ТАРТИБГА СОЛИШ БЎЙИЧА ЕВРОПА ИТТИФОҚИ ТАЖРИБАСИ. ЮРИСТ АХБОРОТНОМАСИ, 2(1), pp.119-131.

4. Bekzod, M., 2015, October. Experience of Uzbekistan in terms of legal regulation of 
foreign citizens' labor activities. In The Eighth International Scientific Conference on Private and Public Law (p. 64).

5. Мусаев Бекзод МЕЖДУНАРОДНОЕ ЧАСТНО-ПРАВОВОЕ РЕГУЛИРОВАНИЕ ТРУДОВЫХ ОТНОШЕНИЙ В УЗБЕКИСТАНЕ: УНИФИКАЦИЯ ПРАВА И СОСТОЯНИЕ КОЛЛИЗИОННОГО ЗАКОНОДАТЕЛЬСТВА // Review of law sciences. 2020. №Спецвыпуск. URL: https://cyberleninka.ru/article/n/mezhduna rodnoe-chastno-pravovoe-regulirovanietrudovyh-otnosheniy-v-uzbekistaneunifikatsiya-prava-i-sostoyaniekollizionnogo (дата обращения: 03.04.2021).

6. Yakubov Sh. U. Digitalization of public control. Psychology and education (2021) 58(2): 1346-1352 doi:https://doi.org/10.17762/pae.v58i2.2281

7. Bekov I. Constitutional and legal basics for the participation of political parties in the formation of the Legislative Chamber of the Oliy Majlis //Journal of Critical Reviews. - 2020. - T. 7. - №. 11. - C. 1571-1577.

8. Kosimov Botirjon Ma'rufjon o'g'li THREATS TO JUDICIAL INDEPENDENCE: REFLECTIONS ON THE US EXPERIENCE // TSUL Legal Report. 2020. №1. URL: https://cyberleninka.ru/article/n/threats-tojudicial-independence-reflections-on-theus-experience (дата обращения: 15.03.2021).

9. НАРИМАНОВ Б. ЎЗБЕКИСТОНДА НОДАВЛАТ НОТИЖОРАТ ТАШКИЛОТЛАР ТАРИХИ ВА РИВОЖЛАНИШИНИНГ АСОСИЙ ТЕНДЕНЦИЯЛАРИ //ЮРИСТ АХБОРОТНОМАСИ. - 2020. - Т. 1. - №. 3. C. 18-29.

10. Alieva K. Gender equality during a pandemic: the problem of domestic violence // Review of law sciences. - 2020. - №2. p. 69-73. URL: https://cyberleninka.ru/article/n/genderno e-ravenstvo-vo-vremya-pandemiiproblema-semeyno-bytovogo-nasiliya

11. Аслонова, Л., 2021. Historical origins and the role of the upper house of parliament in states with a bicameral parliamentary system. Общество и инновации, 2(1/S), pp.104-108.

12. Ботиров, Х., 2020. ПРОБЛЕМЫ КОНСТИТУЦИОНАЛИЗМА В УЗБЕКИСТАНЕ. Review of law sciences, 3(Спецвыпуск).

13. Decree of the President of the Republic of Uzbekistan of February 7, 2017 No. DP-4947 "On the Action Strategy for further development of the Republic of Uzbekistan" // Collection of Legislation of the Republic of Uzbekistan, 2017, No. 6, Article 70.

14. Bulletin of the Supreme Council of the Republic of Uzbekistan, 1993, No.1, Article 4. 